\title{
The Effect of Probiotics on Various Diseases and their Therapeutic Role: An Update Review
}

\author{
Fataneh Hashempour-Baltork ${ }^{1}$ (D), Mahdieh Sheikh ${ }^{1}$, Sevda Eskandarzadeh ${ }^{2}$, \\ Fatih Tarlak ${ }^{3}$, Abhishek Dutt Tripathi ${ }^{4}$, Kianoush Khosravi-Darani ${ }^{1 *}$ \\ and Amankeldy Sadanov ${ }^{5}$
}

${ }^{1}$ Department of Food Science and Technology, National Nutrition and Food Technology Research Institute, Faculty of Nutrition Science and Food Technology, Shahid Beheshti University of Medical Sciences, Tehran, Iran. ${ }^{2}$ Department of Nutrition, School of Public Health, Iran University of Medical Sciences, Tehran, Iran.

${ }^{3}$ Department of Nutrition and Dietetics, Faculty of Health Science, Istanbul Gedik University, Istanbul, Turkey. ${ }^{4}$ Department of Dairy Science and Food Technology, Institute of Agricultural Sciences, Banaras Hindu University, Varanasi - 22105, Uttar Pradesh, India. ${ }^{5}$ Department of Science, Ministry of education and science, Institute of Microbiology and Virology, Almaty, Kazakhstan.

\begin{abstract}
Probiotic bacteria play a critical and functional role in clinical and nutritional applications. In the present study, the ability of various probiotics and their metabolites in the prevention and treatment of different diseases, infection and disorders was reviewed. The issues that were noticed are included: Fibrocystic, diabetes, acne, colon cancer, cardiovascular, urinary tract infections, atopic eczema syndrome, food allergies and obesity. Enhancement in using drug treatment has led to the appearance of drug-resistance concern, thus probiotics can be a suitable choice. This review focuses on the effect of probiotic bacteria and their metabolites on immune-boosting, prevention and treatment of these diseases. For this purpose, after a short glance at each disease, infection and disorder, the mechanism of probiotic action and recent studies about that disease are reviewed. It could be recommended that probiotics consumption, perhaps from birth to all stages of life, would be effective in the life-long, development of health effects and disease treatments.
\end{abstract}

Keywords: Probiotic, disease, fibrocystic, acne, urinary tract infections, atopic eczema syndrome

*Correspondence: kiankh@yahoo.com; 98-21-22086348

(Received: June 09, 2021; accepted: June 30, 2021)

Citation: Hashempour-Baltork F, Sheikh M, Eskandarzadeh S, et al. The Effect of Probiotics on Various Diseases and their Therapeutic Role: An Update Review. J Pure App/ Microbiol. 2021;15(3):1042-1058. doi: 10.22207/JPAM.15.3.17

(C) The Author(s) 2021. Open Access. This article is distributed under the terms of the Creative Commons Attribution 4.0 International License which permits unrestricted use, sharing, distribution, and reproduction in any medium, provided you give appropriate credit to the original author(s) and the source, provide a link to the Creative Commons license, and indicate if changes were made. 


\section{INTRODUCTION}

Governmental guidelines including united nations of Food and Agriculture Organization (FAO) and the World Health Organization (WHO), reported that there are four group of complications in patients with medical conditions, which are: Systemic infections, detrimental metabolic activity, overstimulation of immunocompromised individuals, and gene transfer ${ }^{1}$. Some of disorders side effects have been reported in the gastrointestinal tract, such as vomiting, nausea, spasms, diarrhea, bloating, thirst, and taste disturbances ${ }^{2}$. Some of them can change the natural microbial flora of the skin and irritate the skin rash and acne ${ }^{3}$. The human intestinal flora contains a variety of bacteria species. Environmental stresses and illnesses can lead to disruption in intestinal flora balance. Some of these bacteria are known as probiotic which addition to digestion aid, produce complex compounds such as vitamins and antibiotics and can be helpful for the body. According to WHO and FAO, probiotics are defined as "living microorganisms whose adequate consumption reveals the health effects of the host" ${ }^{\prime 4}$.

Different mechanisms have been considered for probiotics in treatment or prevention of several diseases. The prevention of bacterial adhesion; increase in mucosal barrier function; modulation of immune systems (dendritic cells and T cells); bioactive metabolites; and regulation of the nervous systems ${ }^{4}$. Probiotics by stimulation of lactase activity and assistance in lactose digestion can be useful against various diarrhea and lactose intolerance diseases. They can use enzymatic mechanisms to block toxin-mediated pathology and modify toxin receptors ${ }^{5}$. Other suggested mechanisms for influencing intestinal microflora include lowering intestinal $\mathrm{pH}$, releasing intestinal protective metabolites, regulating intestinal motility, and mucus production. In addition, Lactobacillus (L.) sp. bind to mutagenic compounds in the gut, preventing or delaying tumor progression and cancer ${ }^{6}$. This ability has been linked to the modification of intestinal microflora and the reduction of beta-glucuronidase and other carcinogenic levels ${ }^{7}$. Furthermore, the most significant property of probiotics is the increase in the amount of IgA-producing cells, which is effective in controlling allergies. The onset of an immune signal appeared when a non-pathogenic probiotic bacterium interacts with intestinal epithelial cells and immune cells. Overall, an ideal probiotic should be generally recognized as safe, resistant to bile, hydrochloric acid and pancreatic water, has anti-cancer activity, reduces intestinal permeability, produces lactic acid, stimulate the immune system, resistant to both acidic (stomach) and alkaline (duodenal) conditions ${ }^{8,9}$. In order to have a sufficient health benefit, it is better to use a dose of 5 billion colony forming units (CFU) per day for at least 5 days $^{10}$.

Incorporation of probiotics in several foods are reported e.g. doogh ${ }^{11}$, cheese ${ }^{12}$, fermented drink $^{13}$, yogurt ${ }^{14}$, fermented milks ${ }^{15}$, grape drink ${ }^{16}$, chocolate ${ }^{17}$, fruit juice ${ }^{18}$ etc. Probiotics also produces many useful metabolites during their growth and metabolism e.g. production of bioactive compounds, conjugated linolenic acid $^{19}$, propionic acid ${ }^{13}$, etc. Recently, reduction of oxidative stress and inflammatory factors ${ }^{20}$, removal of toxins and heavy metals ${ }^{21}$ are reported for these amazing microorganisms. Reduction of oxalate by some probiotics propose suggestion of their usage to overcome problem of patients with high risk of oxalate kidney stone due to reduction of oxalate content in colon ${ }^{22,23}$. Increasing knowledge on human intestinal microbiota and microbiota development enables the design of new more specific and hitherto unknown probiotics and prebiotics ${ }^{24,25}$. Also, they can be used instead of drug treatments and lead to prevent the drug resistance issue ${ }^{26}$.

Based on research and studies, the aim of the present paper was to evaluate the ability of probiotics on fibrocystic diseases, diabetes, acne, colorectal cancer, skin, cardiovascular, urinary tract infections, atopic eczema syndrome and also their roles in weight loss, dentistry and prevention of food allergies and lactose intolerance.

\section{The effect of probiotics on different diseases Cystic fibrosis disease}

Fibrosis cyst (CF) is a genetic disease which is triggered by a mutation in fibrocystic membrane regulator gene. It develops from the epithelium of various body organs including the respiratory and gastrointestinal tracts. This disorder causes weakness and adhesion of the mucosa and also lead to inflammation and chronic 
infection in the lungs, which associated with gradual destruction of lung function ${ }^{27,28}$. The same pathophysiology occurs in the gastrointestinal tract. Pancreatic insufficiency, malabsorption, immobility, functional symptoms lead to increase in small intestinal bacteria, which caused to intestinal obstruction ${ }^{29}$. By using live bacteria such as probiotics, they can alter the host's epithelial and immunological responses or affect the function of microbiota ${ }^{28}$. Probiotics can help to improve microbial balance which altered by continued use of antimicrobial drugs to prevent and treat respiratory exacerbation $\mathrm{s}^{30}$. In order to determine the effect of probiotics on pulmonary exacerbations and inflammatory characteristics of the sputum, a study was conducted in 2010 in $10 \mathrm{CF}$ patients, for 6 months. Two tablet of mixed probiotics (L. acidophilus, L. bulgaricus, Bifidobacterium (B.) bifidum, Streptococcus (S.) thermophiles) with each tablet containing $6 \times$ $10^{9} \mathrm{CFU}$, prepared for intake by patients each day. Results indicated probiotics could lessen pulmonary exacerbations rate and may have a inhibition action for pulmonary deterioration in CF patients ${ }^{31}$.

Possible mechanisms of action can help fibrocystic patients by affecting intestinal microbiota including changes in intestinal motility, improving intestinal barrier function, inhibiting the colonization of pathogenic bacteria, improving metabolic processes, and intestinal modulation ${ }^{27,32}$. In other study 20 patients with cystic fibrosis exposed with $L$. rhamnosus LGG $10^{11} \mathrm{CFU}$, twice daily for a month. Results reported improvement in abdominal comfort ( $81 \%)$, reduction in number of stools (56\%) and stool fat and sugar. Probiotics lead to improvement in both clinical and biochemical gastral function in CF patients ${ }^{33}$. Probiotic diminish fecal calprotectin (abdominal inflammation marker) due to CF. It could lessen the CF side effects including vomiting, diarrhea and allergic responses ${ }^{34}$. Literatures suggests that probiotics could be useful in controlling the gastral inflammation in CF disease and improve the intestinal ${ }^{31}$.

\section{Diabetes}

Diabetes is a disease that occurs in high level of blood sugar. Insulin, a hormone made by the pancreas, is require to enter the food glucose to cells to use as energy. In diabetes, body does not get enough insulin and does not use insulin well and then glucose remains in blood freely, without reaching to the cells. Type 1 diabetes is an organ-specific autoimmune disease that occurs in people with a genetic history. The second type is a metabolic illness and is associated with elevated blood glucose, relative insulin deficiency or insulin resistance ${ }^{35}$. In the type I, which are endogenous antigens of $\beta$-pancreatic cells, are identified and acted upon directly or indirectly. Therefore, strategies should be developed to delay or prevent the autoimmune destruction of beta cells. Literatures indicate the gastrointestinal contribution in the autoimmune disorders. Oral administration of probiotic bacteria modulates local and systemic immune responses. The effects of oral administration of probiotic compound on lean (non-obese) diabetic rats showed that beta cell destruction was reduced and diabetes was prevented ${ }^{36}$. Lean diabetic mice developed a spontaneous form of autoimmune diabetes. It is very similar to human disease and could represent a model for examining possible therapeutic approaches $^{37}$. In the type II diabetes, high level of blood glucose causes spontaneous oxidation of sugars, leading to the production of reactive oxygen species (ROS) and the end products of glycosylation, which exposes the body to oxidative stress and inflammation which resulted in high rise of insulin. This issue has important effect in the progress of type 2 diabetes and its cardiovascular disorders ${ }^{38}$. Literatures have indicated that probiotics can lower the level of insulin and glucose in diabetic mice and delay the problems and complications of diabetes ${ }^{39-41}$. In addition, several studies have shown the effect of lowering blood glucose in humans by probiotics ${ }^{42-44}$. Ejtahed et al., prepared yogurt by L. acidophilus and $B$. lactis in $3.98 \times 10^{9} \mathrm{CFU}$ and used for 6 weeks in type 2 diabetes mellitus. Results indicated that it can have medication use by its antidiabetic effect ${ }^{43}$. In other study, intake of soy milk enriched with the L. plantarum A7 $\left(2 \times 10^{7} \mathrm{CFU}\right)$ at $200 \mathrm{ml} /$ day among 20 person with type 2 diabetes mellitus, could decrease the fasting plasma glucose rather than control group ${ }^{45}$. Furthermore, consumption of probiotic supplement including $L$. acidophilus, L. casei, L. lactis, B. bifidum, B. longum, and B. infantis at $3 \times 10^{10} \mathrm{CFU}$ in $250 \mathrm{ml}$ water twice daily for 12 weeks, among 68 adult with type 2 diabetes 
mellitus, lead to reduction in "fasting plasma glucose, fasting plasma insulin, haemoglobin A1c, homeostatic model assessment of insulin resistance" ${ }^{46}$. Preventing the occurrence or reduction of inflammation is related to reducing the amount of gram-negative pathogenic bacteria in the intestine ${ }^{47}$. Thus, it can be concluded that probiotics can have medication use on type 1 and type 2 diabetes by reducing the destruction of beta cells and reducing inflammation, respectively.

\section{Skin diseases (anti-aging)}

Skin aging includes a complex interaction of intrinsic (genetic and hormonal effects) and external aging (exposure to environmental causes such as ultraviolet (UV) ray, smoking, pollution). Changes in skin aging at the molecular level includes rise in the $\mathrm{pH}$ of skin which reduces its ability to suppress ROS and increases metalloproteinase activity. Preliminary studies have suggested that probiotics and their metabolites may play different roles in skin aging ${ }^{48,49}$.

Most probiotics increases the skin's acidic molecules through their metabolism, which in turn reduce the $\mathrm{pH}$ of their environment, which helps in preventing the dominance of pathogenic bacteria, regulate enzyme activity, and maintain a healthy environment ${ }^{48,50}$. The importance of this issue becomes more apparent when people enter the age of 70 and their skin $\mathrm{pH}$ increases significantly ${ }^{51}$. Furthermore, the antioxidant defense systems could be distrupted due to aging and breakdown several attacks in the environment, free radicals, ROS and cellular damage ${ }^{48}$. Studies show that probiotics can slowdown skin aging by restoring the balance between free radicals and their carriers $^{49,52}$. So one of the strongest environmental factors is ultraviolet radiation exposure which has increased due to photography. This effect occurs in the form of wrinkles and increased fragility in the skin. Its more acute effects are suppression of the immune system ${ }^{53}$. Studies have indicated the effect of probiotics in decreasing the harmful effects of ultraviolet radiation and can be antiaging 54. As an example, the L. johnsonii and carotenoids were administered for 10 weeks to persons and then were exposed to both simulated and natural sunlight. Results indicated that experimental supplementation reduced the UVinduced in "Langerhans cell density" in comparison to placebo, beside augmented the recovery of immune system homeostasis after exposure to UV-ray ${ }^{54}$. Intake of L. plantarum HY7714 $\left(10^{10} \mathrm{cfu} /\right.$ day) for 12 weeks in human volunteer could reduce the skin wrinkle depth, improved the skin gloss, and moisture content and also lead to significant improvement in skin elasticity ${ }^{55}$.

Acne

Acne is a medical term that describes what happens when skin follicles (the part of the skin that connects pores to the sebaceous glands) become clogged. It is an inflammatory disorder of the plasma that results from "enlarged endogenous sebum production, inflammation, keratinization, and bacterial colonization of hair follicles" in the face, neck, and chest ${ }^{56}$. The effects of an oral probiotic ( $L$. acidophilus and $L$. bulgaricus) in 300 patients were studied ${ }^{57}$. Preliminary studies show that probiotics are involved in building the immune system, treating acne, protecting against aging and photography, and reducing the signs of aging skin ${ }^{49}$. Enterococcus faecelis $6400 \mathrm{AU}$ twice a day for 8 week in acne patients, could reduce amount of acne lesions ${ }^{58}$. L. plantarum $1 \%$ and $5 \%$ twice a day lead to reducing erythema, repairing the skin barrier and reducing skin microflora to lessen acne at $5 \%{ }^{59}$. Jung et al. (2013) in a clinical trial showed that oral antibiotics (minocycline) and probiotics (combination of $L$. acidophilus $10^{9}$ CFU, L. delbrueckii $10^{9}$, and B. bifidum $20 \times 10^{9}$ ) can provide synergistic benefits in 12 weeks follow up, especially for inflammatory acne ${ }^{60}$.

\section{Colon cancer}

Cancer is a multifactorial disease in which irregular and uncontrolled cell growth is one of its most prominent features. Colorectal cancer is the growth of cancer cells in the colon or rectum (part of the large intestine) ${ }^{61}$. Various pathogenic bacteria such as Escherichia coli and Clostridium perfringens have mutagenic effect and are associated with the progression of colon cancer ${ }^{62}$. The intestinal microbiota is responsible for the metabolism of nutrients, the production of vitamins, endogenous hormones, and toxic products that can be referred to as carcinogens ${ }^{63}$. On the other hand, this disease occurs due to the abnormal growth of cells that can invade other tissues in the body (metastasize) or multiply in them. So the imbalance of the microbial balance of the colon can increase the growth of carcinogenic bacteria ${ }^{64}$. Probiotics such as Bifidobacterium 


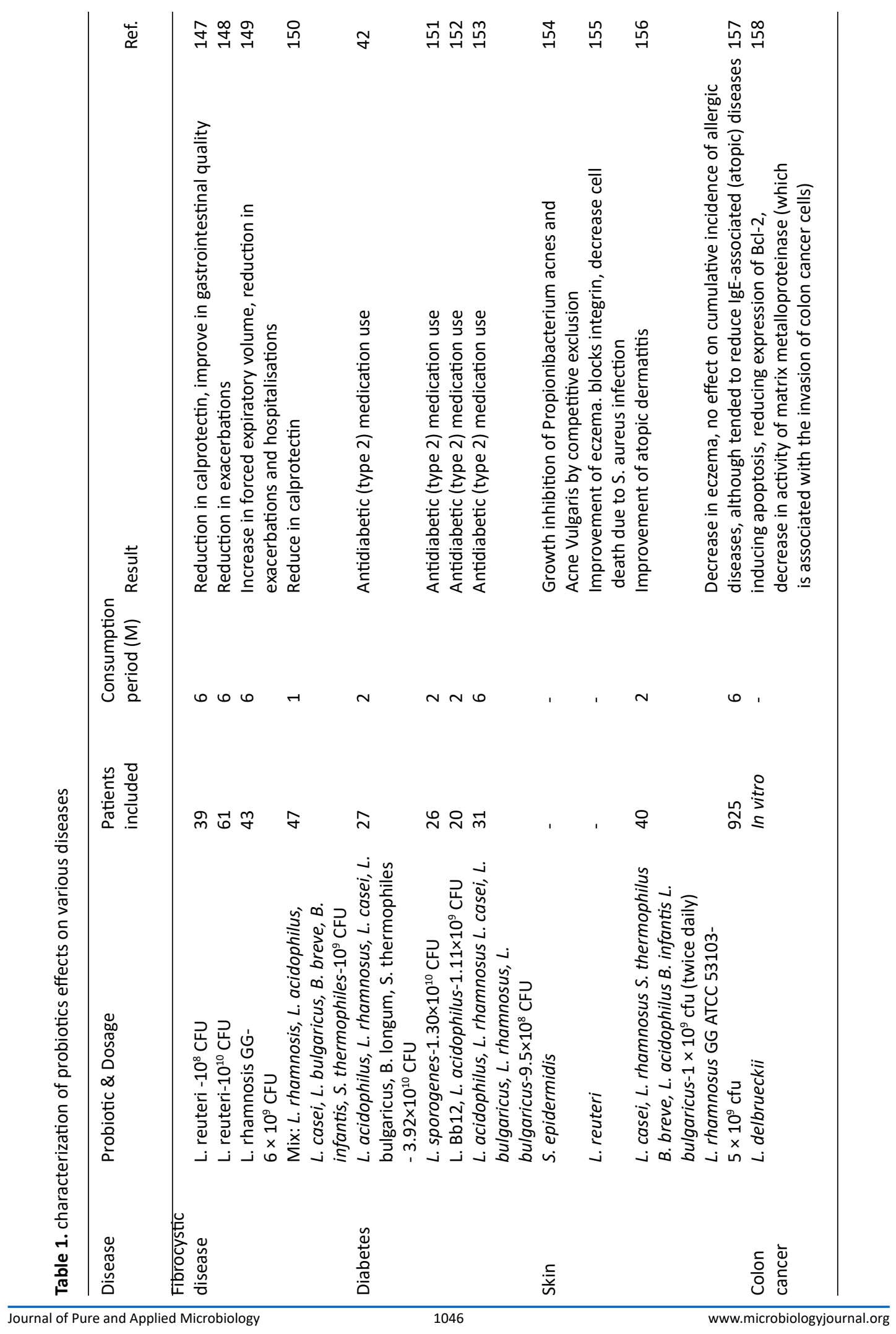




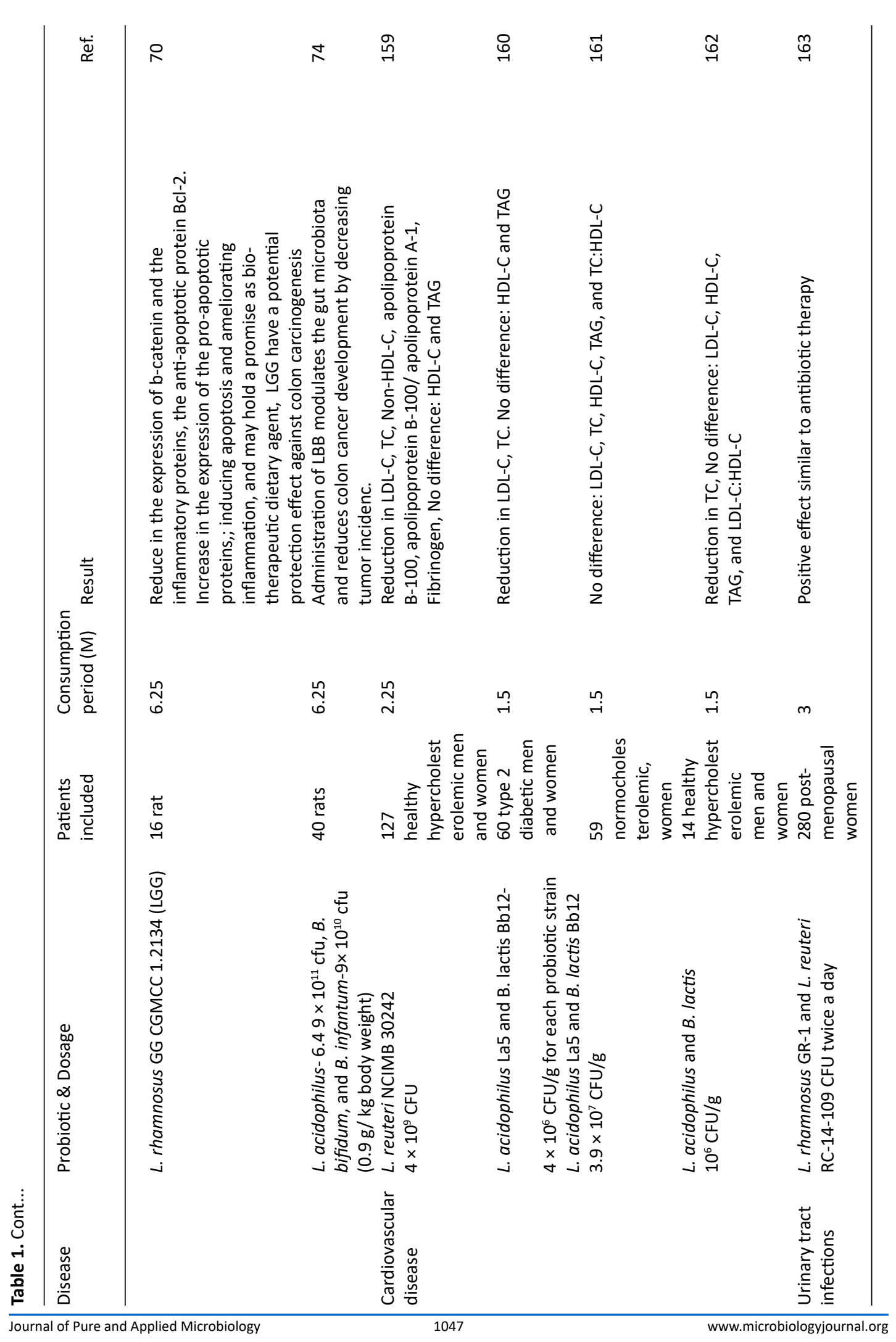




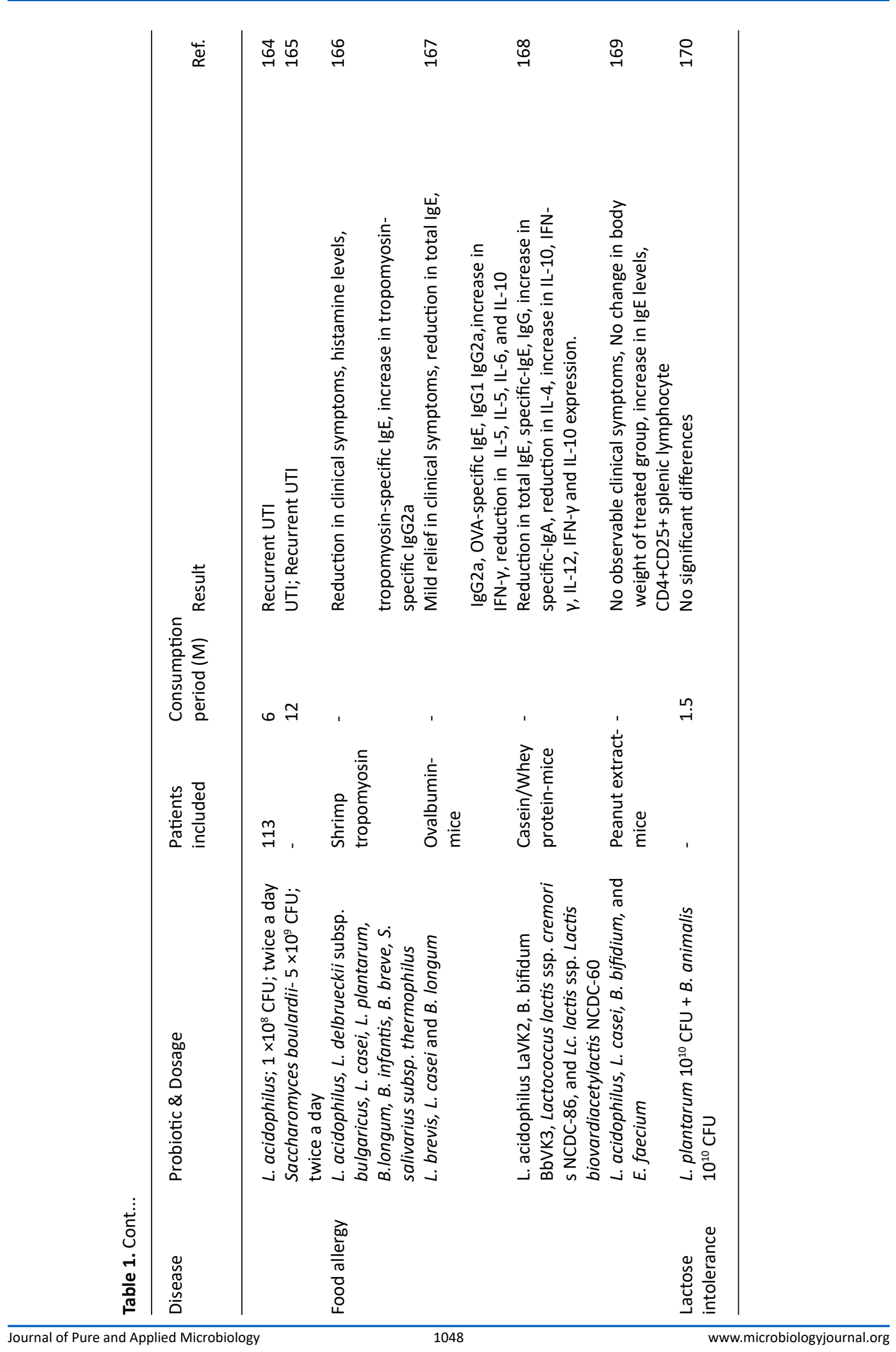


bacteria can selectively inhibit the growth of these pathogenic bacteria and create a favorable environment that modulates bacterial enzymes. Pure Bifidobacteriums have antitumor activity ${ }^{65}$ and activate phagocytes, which affect the immune response and destroy tumor cells in the early stages of growth ${ }^{66}$. For this reason, natural resources that have anti-cancer effects for colon cancer, eg. probiotics, have received considerable attention, recently. Numerous papers have shown that consistent use of probiotics, can advance the quality characteristics of intestinal microbiota and reducing the carcinogenic compound ${ }^{67,68}$. Literature reported various effects of probiotics on conlon cancer including "promotion of epithelial repair and barrier"69, "increased tumor cells apoptosis"70, "prevention of dysbiosis and restoring eubiosis"71, "upregulation of cytokines promoting tissue repair and antitumor responses"72, "production of metabolites with positive effects on the epithelium and immune cells (SCFAs, acetate, propionate, butyrate)"73, "inhibition of biofilm formation and thus cell proliferation via Toll-like receptors"74 and "improvement of adverse events during chemotherapy and radiation therapy"75. They can also have synergistic effect with anti-cancer and immunological drugs ${ }^{76}$. The influencing factors which affect their impact are included: strain, host and their reach route to the large intestine ${ }^{77}$. A study conducted by Hatakka et al., 2008 showed that promoting the consumption of definite strains of probiotics could prevent colon cancer by lessen the activity of harmful bacterial enzymes ${ }^{67}$. Drago, 2019 stated that some selected probiotics can exert anti-cancer activity by physiological mechanisms that are effective in preventing bowel cancer and reducing anti-cancer side effects ${ }^{77}$. Thus, the interaction between probiotics and intestinal microbiota can lead to: neutralizing cancer, improving intestinal barrier function, vitamins and short-chain fatty acids synthesis, altering the intestinal microflora, inhibiting tyrosine kinase, increasing the production of cytokines, antioxidants and anti-angiogenic agents and reducing gastral $\mathrm{pH}$, etc ${ }^{78}$.

\section{Cardiovascular disease}

Cardiovascular disease is a group of illnesses that occur in the heart or arteries (arteries, capillaries, and veins) and affect the circulatory system ${ }^{79}$. Various methods are used to control this disease, including medication, surgery, and lifestyle changes ${ }^{80}$. Probiotics containg materials are one of the special foods that can help in cardiovascular diseases by affecting the health of microorganisms living in the intestine and maintaining the balance between species of symbiotic bacteria and pathogens. One of the key and important factors in treatment and prevention is controlling the level of blood lipids and inflammatory factors that low density lipoproteincholestrole (LDL-C) has been named as the main risk factor ${ }^{81}$. In earlier, probiotics were shown to be effective in lowering cholesterol in tribes that used fermented yogurt ${ }^{82}$. These bacteria, along with other useful components of food, cause changes in metabolic pathways by fermenting dietary fiber and producing short-chain fatty acids, reduce the synthesis of endogenous cholesterol ${ }^{83}$. Other effects include reducing and controlling the level of inflammation in inflammatory markers ${ }^{84}$. Literatures have revealed that probiotics could reduce the cholesterol levels. As example, live $L$. fermentum 11976 led to significant reductions in total cholesterol, triglyceride and LDL-C levels of hypercholesterolemic hamsters ${ }^{85}$. Similar results were observed in rats fed a high cholesterol diet supplemented with lyophilized L. plantarum MA2 led to significant decrease in their total cholesterol, LDL-C and triglyceride levels rather than rat fed only by high cholesterol diet ${ }^{86}$. Recent studies have linked the mechanism of inflammation reduction to improve lipid profile levels ${ }^{87,88}$. Studies showed that dysbiosis in the pathogenesis is directly related to the level of ischemic heart disease and inflammatory cytokines ${ }^{89}$.

\section{Urinary tract infections}

The urinary tract includes the urinary tract and the reproductive tract, and both systems are exposed to the external environment and capable of infection, both external and internal. Internal infections are due to an imbalance in the microorganisms of the urinary tract ${ }^{90}$. The resulting infections involve children to adults and affect the bladder, kidneys, urethra, vagina and cervix. It is one of the most common infections in women and is a global and important problem ${ }^{91}$. Bacterial species in the vaginal mucosa is different between postmenopausal and premenopausal women, and the healthy flora of the premenopausal vaginal mucosa is surrounded by Lactobacillus species ${ }^{92}$. 
Their defensive role depends on their ability to produce antibacterial agents to limit pathogen growth, biosorfactant production, and to form defense system. They produce the biosurfactants that prevent the attachment and binding of pathogens $s^{93}$. The production of lactic acid and the production of an acidic environment in the vagina is another characteristic of them and reduces autophagy in the epithelial cells. This leads to the destruction of intracellular microorganisms and the promotion of homeostasis ${ }^{94}$. Also, the presence of Bifidobacterium strains in the vagina can lead to production of lactic acid and hydrogen peroxide, which act against local infections ${ }^{95}$. Studies have shown that lactobacilli are effective in preventing infections of the urinary tract in women. Lactobacillus. and Bifidobacterium. strains are of the predominant species in probiotics and can use to prevent and treat urinary tract infections ${ }^{96}$. A hospital study of elderly patients admitted to the ICU showed that probiotics $\left(5 \times 10^{7}\right.$ CFU of L. acidophilus, L. rhamnosus, L. gasser and L. Plantarm for twice a day for seven days), could prevent urinary tract infections. Its administration causes a significant change in the microflora of the urinary tract and reduces the colonization of pathogens ${ }^{97}$. The study of meta-analysis findings indicate that probiotics as monotherapy could not have noteworthy effects but its use as adjuvant therapy to antibiotics could have a moderate efficacy on preventing the recurrence of UTI ${ }^{98}$.

\section{Atopic eczema syndrome}

Atopic eczema is an irritated skin disease with an early development. It has augmented in occurrence in recent years and affects up to $25 \%$ and $10 \%$ of teenagers and adults, respectively ${ }^{99}$. Atopic eczema may be inherited, or occur due to contact with allergens or stimulants. Congenital trauma to the fetus may also be a strong indicator of atopic development ${ }^{100}$. This is one of the most usual inflammatory skin disorder in children. Its symptoms include irritable itching, skin damage, pain, lack of sleep, etc. ${ }^{101}$ Literatures show a decrease in the amount of Bifidobacterium in the infant, young children and adults with this disease ${ }^{102,103}$. One of the methods used to treat this disease is to change the mixture of intestinal bacteria and reduce inflammation in the intestine with probiotics ${ }^{104}$. Based on the study conducted by ${ }^{105}$, intake of $L$. johnsonii twice a day for 21 days, on atopic dermatitis patients lead to decrease in Staphylococcus aureus and improve in atopic dermatitis scores ${ }^{105}$. Beside, consumption of Vitreoscilla (V.) filiformis in cream twice a day for 1 month and also Streptococcus thermophilus 1.7 $\mathrm{g} / 5 \mathrm{~mL}$ in $20 \mathrm{~mL}$ lotion, lead to increase in skin ceramides and improvement in all aspects of atopic dermatitis patients ${ }^{106,107}$. Based on the findings of the study it has been found that probiotics can be effective in chronic inflammatory skin disease, atopic eczema by altering the microbial flora of the intestine.

\section{Food allergy}

Food allergy is definite as an adverse immune reaction to dietary proteins and includes a variety of disorders. It affects $6 \%$ of children and $3 \%$ to $4 \%$ of adults. This disease may be caused by Ig-E and non-Ig-E mediated mechanisms by cellular mechanisms ${ }^{108}$. After eating sepecific foods such as tomato, soya bean, egg or etc., Ig-E causes acute allergic disorders due to the involvement of arm cells, cell tissue and blood basophils. Re-exposure to this factor due to the binding of food proteins to specific Ig-E molecules causes the release of mediators such as histamine, which mediate these symptoms. The disease affects various target organs such as the "skin (urticaria, angioedema), the respiratory system (rhinitis, asthma), the gastrointestinal tract (pain, protrusion, and diarrhea) and the cardiovascular system (anaphylactic shock)". The most severe form of intestinal food allergy in infants is "food protein-induced enterocolitis syndrome" which has different symptoms including vomiting, scattered diarrhea, increased neutrophil count, and shock, and is potentially similar to sepsis with dehydration, acidemia, and methaemoglobinaemia ${ }^{109}$.

Probiotics are one of the treatments used to manage patients with food allergies. The exact mechanisms of the effects of probiotics on the disease are unclear. Study on animals showed that that in addition to modulating intestinal microbiota, could improve intestinal mucosal barrier function, reduce leakage of antigens via mucosa, and reduce exposure ${ }^{110}$. Direct modulation of the immune system may be mediated by increased in production of Ig-E or induction of anti-inflammatory cytokines ${ }^{111}$. According to Liu et al., usage of $B$. infantis lead to reduction in $\beta$-Lactoglobulin, total IgE and 
IgG1, signs of inflammation, IL-4, IL-10 and IL$13^{112}$. Probiotic enzymes reduce the load and antigens exposure by enzymatically degrading food antigens ${ }^{113}$. Mechanism of action of probiotics are involved in reducing the immune system's exposure to dietary antigens. Due to the positive role of probiotic bacteria in creating a coherent relationship with the immune system and regulating immune responses to reduce the host sensitivity as well as reducing the symptoms of inflammation, is considered as a new strategy in improving food allergies ${ }^{114}$.

\section{Lactose intolerance}

Researchers have found that many people who think they have a food allergy actually have food intolerances, which are different with each other. Food intolerances do not include Ig-E antibodies. Intolerance may occur due to protein, chemicals, carbohydrates, enzyme deficiencies or decreased intestinal permeability ${ }^{115}$. Lactose intolerance is a common gastrointestinal disorder which is caused by lack of the lactase enzyme in the intestinal wall or an inability to digest lactose into glucose and galactose. Its level estimated at $50 \%$ in $\mathrm{Asia}^{116}$. Lactose intolerance can be observe after consuming lactose containing foods, by symptoms such as abdominal pain, diarrhea, bloating, nausea, vomiting and swelling ${ }^{117}$. The unabsorbed lactose has an osmotic charge and causes the secretion of fluids and electrolytes until it reaches equilibrium. Osmosis dilates the intestines and eventually accelerates the transit of the small intestine. This free lactose is fermented in the large intestine by colon bacteria to produce short-chain fatty acids and hydrogen gas $^{118}$. Also, fermented and non-fermented milk products which containing probiotics can reduce its symptoms and be effective in treating lactose intolerance ${ }^{116}$. Furthermore, dairy products containinmg probiotics improve lactose digestion by slowing the passage of food through the gastrointestinal tract ${ }^{119,120}$, intake of $L$. reuteri $\left(8 \times 10^{8} \mathrm{CFU} /\right.$ day $)$ by 40 lactose intolerant patients, caused to improvement in abdominal pain, bloating, diarrhea, and flatulence ${ }^{120}$. The results showed that probiotics can be effective in treating and preventing lactose intolerance by increasing the enzyme lactase, but still need further investigation.

\section{Probiotics in dentistry}

Dentistry includes the study, diagnosis, inhibition and management of oral diseases and the related disorders. Tooth decay is a multifactorial disease and the most common chronic disease, begins with the dissolution of the mineral part of the tooth and progresses to the local alignment of the enamel and dentin. If caries does not prevent and treat, it will lead to inflammation of the pulp and periapical. This disease has four main causes: bacteria, sugars, predisposing factors and time. The most important pathogens for the initial growth of tooth decay are $S$. mutans and the most important pathogen in the development of caries lesions is Lactobacillus. S. mutans are important because of their characteristics such as their acidity, ability to survive in acidic environments, biofilm formation and cariostatic activity ${ }^{121,122}$. On the surface of the mouth, there are a number of different probiotics that reduce the incidence of tooth decay, gum disease, reduce bad breath and fight oral infection by Candida albicans ${ }^{123}$. The most common strains in the oral cavity, are Lactobacillus and Bifidobacterium strains ${ }^{124,125}$. The mechanism of action of probiotics in the oral cavity is similar to that of intestinal probiotics. Environmental conditions can disrupt the balance of oral bacteria and lead to defect in oral health ${ }^{126-128}$.

A probiotic must be able to adhere to the surface of the tooth and integrate into the bacteria that make up the biofilm, and be able to fight off pathogenic bacteria and prevent them from multiplying. According to ${ }^{129}$ using $S$. thermophiles and L. lactis ssp. which are used in dairy industry, can integrate into surface biofilms and interfere with the development of $S$. sobrinus species $^{129}$. Other study have shown that Weissella cibaria species have the ability to integrate biofilms produced by $S$. mutans and inhibit the reproduction of this bacterium ${ }^{130}$. The application of probiotics may be different, such as chewing gum, milk, cheese, yogurt, ice cream, drops, mouthwash, etc. ${ }^{123}$ In periodontal disease, clinical study has shown the noticeable improvement by using chewing gum or tonsils containing probiotics $^{131}$. There are various studies with proven probiotic activity on oral pathogens including L. casei LC-11 in lessening of cariogenic biofilm potential ${ }^{132}$, L. paracasei in caries management ${ }^{133}$, 
B. animalis subsp. Lacis improved resistance to oral infections ${ }^{134}$ etc. Probiotic techniques for oral health are still a promising area of research. Obviously, more research on the concentration and methods of probiotic uptake is needed to more fully evidences in the beneficial effects of probiotics on oral health.

Obesity

Probiotics are believed to help obesity and weight management by act important role in gut. Obesity is caused by an imbalance between energy intake and consumption, which lead to fat accumulation in body ${ }^{135}$. Two groups of beneficial bacteria residing in the human gut are bacterioids and firmomycetes, and body weight appears to be related to the balance of these two groups of bacteria ${ }^{136,137}$. Studies in humans and animals have shown that the intestinal bacteria of normalweight individuals are more diverse than those of overweight individuals, and that obese individuals have more firmomycetes and fewer bacterioids than normal-weight individual ${ }^{138-140}$. Several animal studies have shown that if the intestinal bacteria of obese mice transfer to the intestines of lean mice, obesity occurred in second group ${ }^{140}$. Therefore, strengthening the intestinal microbiota can play an effective role in weight loss. As mentioned previously in the effect of probiotics on bowel cancer in above, probiotics can alter and improve the gut microbiota. Probiotics can affect weight loss in several ways include : 1 . Some species of the Lactobacillus family prevent the absorption of dietary fat in the body and thus increase the fat excreted in the feces ${ }^{141,2}$. They help to secrete an appetite suppressant hormone called GLP-1. When the level of secretion of this hormone increases, the level of calorie burning and fat burning in the body also increases ${ }^{142,3}$. Increase the level of ANGPTL4 protein and reduce fat storage ${ }^{143,4}$. In addition, there is some evidence linking obesity to inflammation of the brain. Probiotics can reduce inflammation in various organs of the body, such as the brain, and prevent obesity by improving intestinal health ${ }^{144}$. According to literatures, $L$. gasseri SBT2055 (LG2055) and L. plantarum TENSIA lead to reduction in abdominal adiposity and body weight $^{145,146}$. Although many studies confirm the effect of probiotics on obesity, more research is needed on their mechanism of action.

\section{CONCLUSION}

Probiotics and their metabolites as biological control agents play an important role in prevention and treatment of various diseases, especially those related to the gastrointestinal tract. This role of probiotics became more important with the industrialization of the world, increase ready to eat food consumption, stressful condition, heavy metal contamination of water and weather, which lead to reduction of some beneficial bacteria. In other hand, development in using drug treatment for different diseases lead to enhancement of drug-resistant issue which can result in some problems including treatment failure, increased mortality as well as treatment costs, reduced infection control efficiency, and spread of resistant pathogens from hospital to community. Probiotic consumption in diferernt ways, could be a safe choice for boosting immune system, prevention and treatment of different diseases including fibrocystic, diabetes, acne, colon cancer, cardio vascular, urinary tract infections, atopic eczema syndrome, food allergies and obesity which are focused in present study. Based on study on literatures, probiotics had important role in inhibition or treatment of various diseases. Although, some papers indicate no significant effect associate to probiotica role. Certainly, future research is suggest to determining the best probiotic and its ideal dose for each disease.

\section{ACKNOWLEDGMENTS}

We would like to thank the "Student Research Committee" and "Research \& Technology Chancellor" in Shahid Beheshti University of Medical Sciences for their financial support of this study.

\section{CONFLICT OF INTEREST}

The authors declare that there is no conflict of interest.

\section{AUTHORS' CONTRIBUTION}

KK conceptualize and supervised the study. FH applied methodology and did the investigation. MS contributed to software work and wrote the draft. SE did the validation and grammatical editing. FT performed the formal 
analysis. ADT administered the project. AS completed the final review and edited the manuscript. All listed authors have read and approved the final manuscript for publication.

\section{FUNDING}

This study is related to the project NO.27469 stimulated to Student Research Committee, Shahid Beheshti University of Medical Sciences, Tehran, Iran.

\section{DATA AVAILABILITY}

All datasets generated or analyzed during this study are included in the manuscript.

\section{ETHICS STATEMENT}

Not applicable.

\section{REFERENCES}

1. WHO. FAO/WHO Framework for the Provision of Scientific Advice on Food Safety and Nutrition: Food \& Agriculture Org. 2007.

2. Goldenberg JZ, Yap C, Lytvyn L, et al. Probiotics for the prevention of Clostridium difficile-associated diarrhea in adults and children. Cochrane Database Syst Rev. 2017;12(12):CD006095. doi: 10.1002/14651858. CD006095.pub4

3. Salminen MK, Rautelin H, Tynkkynen $\mathrm{S}$, et al. Lactobacillus bacteremia, clinical significance, and patient outcome, with special focus on probiotic $L$. rhamnosus GG. Clin Infect Dis. 2004;38(1):62-69. doi: 10.1086/380455

4. Liu Y, Tran DQ, Rhoads JM. Probiotics in disease prevention and treatment. J Clin Pharmacol. 2018;58(Suppl 10):S164-S179. doi: 10.1002/jcph.1121

5. Bajaj BK, Claes IJJ, Lebeer S. Functional mechanisms of probiotics. J Microbiol Biotechnol Food Sci. 2015;4(4):321-327. doi: 10.15414/ jmbfs.2015.4.4.321-327

6. Bedada TL, Feto TK, Awoke KS, Garedew AD, Yifat FT, Birri DJ. Probiotics for cancer alternative prevention and treatment. Biomed Pharmacother. 2020;129:110409. doi: 10.1016/j.biopha.2020.110409

7. Chandel D, Sharma M, Chawla V, Sachdeva N, Shukla G. Isolation, characterization and identification of antigenotoxic and anticancerous indigenous probiotics and their prophylactic potential in experimental colon carcinogenesis. Scientific Reports. 2019;9:14769. doi: 10.1038/s41598-019-51361-z

8. Arvola T, Laiho K, Torkkeli S, et al. Prophylactic Lactobacillus GGReduces Antibiotic-Associated Diarrhea in Children With Respiratory Infections: A Randomized Study. Pediatrics. 1999;104(5):e64. doi: 10.1542/peds.104.5.e64

9. Amalaradjou MAR, Bhunia AK. Modern approaches in probiotics research to control foodborne pathogens. Adv Food Nutr Res. Elsevier. 2012;67:185-239. doi:
10.1016/B978-0-12-394598-3.00005-8

10. Ouwehand A. A review of dose-responses of probiotics in human studies. Beneficial Microbes. 2017;8(2):143151. doi: 10.3920/BM2016.0140

11. Rahmdar SR, Roudsari MR, Javanmard A, Mortazavian AM, Sohrabvandi S. The Impact of Inoculation Rate and Order on Physicochemical, Microstructural and Sensory Attributes of Probiotic Doogh. Iran J Pharm Res.2013;12(4):917-924. PMID: 24523772

12. Nezami MA, Ehsani MR, Mohammadi-Sani A, KhosraviDarani K. Optimization of Lactobacillus acidophilus La-5, Feta Cheese Starters and Salt Content in Iranian Ultrafiltered Soft Cheese Formula. Annu Res Rev Biol. 2014;4(24):4091-4103. doi: 10.9734/ ARRB/2014/11101

13. Ahmadi N, Khosravi-Darani K, Zarean-Shahraki S, Mortazavian M, Mashayekh S. Fed-batch fermentation for propionic, acetic and lactic acid production. Oriental Journal of Chemistry. 2015;31(1):581-590. doi: 10.13005/ojc/310174

14. Massoud R, Fadaei V, Khosravi-Darani K, Nikbakht HR. Improving the viability of probiotic bacteria in yoghurt by homogenization. Journal of Food Processing and Preservation. 2015;39(6):2984-2990. doi: 10.1111/ jfpp.12551

15. Beheshtipour H, Mortazavian A, Mohammadi R, Sohrabvandi S, Khosravi-Darani K. Supplementation of Spirulina platensis and Chlorella vulgaris algae into probiotic fermented milks. Comprehensive Reviews in Food Science and Food Safety. 2013;12(2):144-154. doi: 10.1111/1541-4337.12004

16. Malganji S, Sohrabvandi S, Jahadi M, Nematollahi A, Sarmadi B. Effect of refrigerated storage on sensory properties and viability of probiotic in grape drink. Applied Food Biotechnology. 2016;3(1):59-62. doi: 10.22037/afb.v3i1.10544

17. Ghasemnezhad R, Razavilar V, Pourjafar H, KhosraviDarani K, Ala K. The viability of free and encapsulated Lactobacillus casei and Bifidobacterium animalis in chocolate milk, and evaluation of its $\mathrm{pH}$ changes and sensory properties during storage. Annu Res Rev Biol. 2017;21(3):1-8. doi: 10.9734/ARRB/2017/37885

18. Chackoshian KA, Shojaosadati SA. Improvement of probiotic survival in fruit juice and under gastrointestinal conditions using pectin-nanochitin-nanolignocellulose as a novel prebiotic gastrointestinal-resistant matrix. Applied Food Biotechnology. 2017;4(3):179-191. doi: 10.22037/afb.v4i3.17337

19. Farhadi S, Khosravi-Darani K, Mashayekh M, Mortazavian AM, Mohammadi A, Shahraz F. Production of propionic acid in a fermented dairy beverage. International Journal of Dairy Technology. 2013;66(1):127-134. doi: 10.1111/1471-0307.12004

20. Eskandarzadeh S, Effatpanah M, Khosravi-Darani $\mathrm{K}$, et al. Efficacy of a multispecies probiotic as adjunctive therapy in generalized anxiety disorder: a double blind, randomized, placebo-controlled trial. Nutr Neurosci. 2021;24(2):102-108. doi: 10.1080/1028415X.2019.1598669

21. Hadiani MR, Khosravi-Darani K, Rahimifard N. Optimization of As (III) and As (V) removal by Saccharomyces cerevisiae biomass for biosorption 
of critical levels in the food and water resources. J Environ Chem Eng. 2019;7(2):102949. doi: 10.1016/j. jece.2019.102949

22. Karamad D,Darani KK, Hosseini H, Tavasoli S, Miller AW. Assessment of the Process Variables for Degradation of Oxalate by Lactobacillus acidophilus ATCC 4356 Using Simulated Rumen Fluid Media and Tea. Applied Food Biotechnology. 2020;7(4):195-204. doi: 10.22037/afb. v7i4.28600

23. Hashempour-Baltork F, Hosseini SM, Assarehzadegan MA, Khosravi-Darani K, Hosseini H. Safety assays and nutritional values of mycoprotein produced by Fusarium venenatum IR372C from date waste as substrate. J Sci Food and Agri. 2020;100(12):44334441. doi: 10.1002/jsfa.10483

24. Hashempour-Baltork F, Khosravi-Darani K, Hosseini $\mathrm{H}$, Farshi P, Reihani SFS. Mycoproteins as safe meat substitutes. J Clean Prod. 2020;253:119958. doi: 10.1016/j.jclepro.2020.119958

25. Gallego CG, Salminen S. Novel probiotics and prebiotics: how can they help in human gut microbiota dysbiosis? Applied Food Biotechnology. 2016;3(2):7281. doi: $10.22037 / a f b . v 3 i 2.11276$

26. Hashempour-Baltork F, Hosseini H, Shojaee-Aliabadi S, Torbati M, Alizadeh AM, Alizadeh M. Drug resistance and the prevention strategies in food borne bacteria: An update review. Adv Pharm Bull. 2019;9(3):335-347. doi: 10.15171/apb.2019.041

27. Li L, Somerset S. The clinical significance of the gut microbiota in cystic fibrosis and the potential for dietary therapies. Clin Nutrn. 2014;33(4):571-580. doi: 10.1016/j.clnu.2014.04.004

28. Rogers GB, Carroll M, Hoffman L, Walker A, Fine D, Bruce K. Comparing the microbiota of the cystic fibrosis lung and human gut. Gut Microbes. 2010;1(2):85-93. doi: 10.4161/gmic.1.2.11350

29. De Lisle RC, Borowitz D. The cystic fibrosis intestine. Cold Spring Harb Perspect Med. 2013;3(9):a009753. doi: 10.1101/cshperspect.a009753

30. Gollwitzer ES, Marsland BJ. Microbiota abnormalities in inflammatory airway diseases-Potential for therapy. Pharmacology \& Therapeutics. 2014;141(1):32-39. doi: 10.1016/j.pharmthera.2013.08.002

31. Weiss B, Bujanover $Y$, Yahav $Y$, Vilozni D, Fireman E, Efrati O. Probiotic supplementation affects pulmonary exacerbations in patients with cystic fibrosis: a pilot study. Pediatric Pulmonology. 2010;45(6):536-540. doi: 10.1002/ppul.21138

32. Whelan K, Quigley EM. Probiotics in the management of irritable bowel syndrome and inflammatory bowel disease. Curr Opin Gastroenterol. 2013;29(2):184-189. doi: 10.1097/MOG.0b013e32835d7bba

33. Infante DP, Redecillas SF, Torrent AV, et al. Improvement of intestinal function in cystic fibrosis patients using probiotics. An Pediatr (Barc). 2008;69(6):501-505. doi: 10.1016/S1695-4033(08)75231-7

34. Coffey MJ, Garg M, Homaira N, Jaffe A, Ooi CY. Probiotics for people with cystic fibrosis. Cochrane Database Syst Rev. 2020;(1). doi: 10.1002/14651858. CD012949.pub2

35. Ruggiero L, Castillo A, Quinn L, Hochwert M. Translation of the diabetes prevention program's lifestyle intervention: role of community health workers. Curr Diab Rep. 2012;12(2):127-137. doi: 10.1007/s11892012-0254-y

36. Calcinaro F, Dionisi S, Marinaro M, et al. Oral probiotic administration induces interleukin-10 production and prevents spontaneous autoimmune diabetes in the non-obese diabetic mouse. Diabetologia. 2005;48(8):1565-1575. doi: 10.1007/s00125-005$1831-2$

37. Adorini L, Gregori S, Harrison LC. Understanding autoimmune diabetes: insights from mouse models. Trends Mol Med. 2002;8(1):31-38. doi: 10.1016/S14714914(01)02193-1

38. Yadav H, Jain S, Sinha PR. Oral administration of dahi containing probiotic Lactobacillus acidophilus and Lactobacillus casei delayed the progression of streptozotocin-induced diabetes in rats. J Dairy Res. 2008;75(2):189-195. doi: 10.1017/ S0022029908003129

39. Al-Salami H, Butt G, Tucker I, Skrbic R, Golocorbin-Kon $S$, Mikov M. Probiotic Pre-treatment Reduces Gliclazide Permeation (ex vivo) in Healthy Rats but Increases It in Diabetic Rats to the Level Seen in Untreated Healthy Rats. Archives of Drug Information. 2008;1(1):35-41. doi: 10.1111/j.1753-5174.2008.00006.x

40. Tabuchi M, Ozaki M, Tamura A, et al. Antidiabetic effect of Lactobacillus GG in streptozotocin-induced diabetic rats. Biosci Biotechnol Biochem. 2003;67(6):14211424. doi: 10.1271/bbb.67.1421

41. Yadav H, Jain S, Sinha P. Antidiabetic effect of probiotic dahi containing Lactobacillus acidophilus and Lactobacillus casei in high fructose fed rats. Nutrition. 2007;23(1):62-68. doi: 10.1016/j.nut.2006.09.002

42. Asemi Z, Zare Z, Shakeri H, Sabihi S-S, Esmaillzadeh A. Effect of multispecies probiotic supplements on metabolic profiles, hs-CRP, and oxidative stress in patients with type 2 diabetes. Ann Nutr Metab. 2013;63(1-2):1-9. doi: 10.1159/000349922

43. Ejtahed HS, Mohtadi-Nia J, Homayouni-Rad A, Niafar M, Asghari-Jafarabadi M, Mofid V. Probiotic yogurt improves antioxidant status in type 2 diabetic patients. Nutrition. 2012;28(5):539-543. doi: 10.1016/j. nut.2011.08.013

44. Moroti C, Magri LFS, de Rezende Costa M, Cavallini DC, Sivieri K. Effect of the consumption of a new symbiotic shake on glycemia and cholesterol levels in elderly people with type 2 diabetes mellitus. Lipids Health Dis. 2012;11(1):29. doi: 10.1186/1476-511X-11-29

45. Feizollahzadeh S, Ghiasvand R, Rezaei A, Khanahmad $\mathrm{H}$, Hariri M. Effect of probiotic soy milk on serum levels of adiponectin, inflammatory mediators, lipid profile, and fasting blood glucose among patients with type II diabetes mellitus. Probiotics and Antimicrobial Proteins. 2017;9(1):41-47. doi: 10.1007/s12602-0169233-y

46. Firouzi S, Majid HA, Ismail A, Kamaruddin NA, Barakatun-Nisak M-Y. Effect of multi-strain probiotics (multi-strain microbial cell preparation) on glycemic control and other diabetes-related outcomes in people with type 2 diabetes: a randomized controlled trial. $E u$ Jo Nutr. 2017;56(4):1535-1550. doi: 10.1007/s00394016-1199-8 
47. Lye HS, Kuan CY, Ewe JA, Fung WY, Liong MT. The improvement of hypertension by probiotics: effects on cholesterol, diabetes, renin, and phytoestrogens. Int J Mol Sci. 2009;10(9):3755-3775. doi: 10.3390/ ijms10093755

48. Cinque $B$, Palumbo $\mathrm{P}$, La Torre $\mathrm{C}$, et al. Probiotics in aging skin. In: Farage MA, Miller KW, Maibach $\mathrm{HI}$, eds. Textbook of Aging Skin. Springer Berlin Heidelberg. 2010:811-820. doi: 10.1007/978-3-540-89656-2 78

49. Kober M-M, Bowe WP. The effect of probiotics on immune regulation, acne, and photoaging. Int $J$ Womens Dermatol. 2015;1(2):85-89. doi: 10.1016/j. ijwd.2015.02.001

50. Mauro T. SC pH: measurement, origins, and functions. Skin Barrier New York: Taylor \& Francis Group. 2006:223-230.

51. Hachem J-P, Crumrine D, Fluhr J, Brown BE, Feingold KR, Elias PM. pH directly regulates epidermal permeability barrier homeostasis, and stratum corneum integrity/ cohesion. J Invest Dermatol. 2003;121(2):345-353. doi: 10.1046/j.1523-1747.2003.12365.x

52. Angelica Garrido-Pereira M, Braga AL, Rocha AFd, Sampaio LA, Abreu PC. Effect of ultraviolet (UV) radiation on the abundance and respiration rates of probiotic bacteria. Aquaculture Research. 2013;44(2):261-267. doi: 10.1111/j.1365-2109.2011.03029.x

53. Schwarz A, Schwarz T. Molecular determinants of UV-induced immunosuppression. Exp Dermatol. 2002;11:9-12. doi: 10.1034/j.1600-0625.11.s.1.3.x

54. Bouilly-Gauthier D, Jeannes C, Maubert $Y$, et al. Clinical evidence of benefits of a dietary supplement containing probiotic and carotenoids on ultravioletinduced skin damage. Br J Dermatol. 2010;163(3):536543. doi: 10.1111/j.1365-2133.2010.09888.x

55. Lee DE, Huh C-S, Ra J, et al. Clinical evidence of effects of Lactobacillus plantarum HY7714 on skin aging: a randomized, double blind, placebo-controlled study. Journal of Microbiology and Biotechnology. 2015;25(12):2160-2168. doi: 10.4014/jmb.1509.09021

56. Williams HC, Dellavalle RP, Garner S. Acne vulgaris. The Lancet. 2012;379(9813):361-372. doi: 10.1016/ S0140-6736(11)60321-8

57. Bowe W, Patel N, Logan A. Acne vulgaris, probiotics and the gut-brain-skin axis: from anecdote to translational medicine. Beneficial Microbes. 2014;5(2):185-199. doi: 10.3920/BM2012.0060

58. Kang BS, Seo J-G, Lee G-S, et al. Antimicrobial activity of enterocins from Enterococcus faecalis SL-5 against Propionibacterium acnes, the causative agent in acne vulgaris, and its therapeutic effect. J Microbiol. 2009;47(1):101-109. doi: 10.1007/s12275-008-0179-y

59. Muizzuddin N, Maher W, Sullivan M, Schnittger S, Mammone T. Physiological effect of a probiotic on skin. J Cosm Sci. 2012;63(6):385-395. PMID: 23286870

60. Jung GW, Tse JE, Guiha I, Rao J. Prospective, randomized, open-label trial comparing the safety, efficacy, and tolerability of an acne treatment regimen with and without a probiotic supplement and minocycline in subjects with mild to moderate acne. J Cutan Med Surg. 2013;17(2):114-122. doi: 10.2310/7750.2012.12026

61. Board PATE. Colon Cancer Treatment (PDQ $\left.{ }^{\circledR}\right)$. PDQ
Cancer Information Summaries [Internet]. National Cancer Institute (US). 2020.

62. Gorska A, Przystupski D, Niemczura MJ, Kulbacka J. Probiotic bacteria: a promising tool in cancer prevention and therapy. Curr Microbiol. 2019;76(8):939-949. doi: 10.1007/s00284-019-01679-8

63. Guarner F, Malagelada J-R. Gut flora in health and disease. The Lancet. 2003;361(9356):512-519. doi: 10.1016/S0140-6736(03)12489-0

64. Arthur JC, Jobin C. The struggle within: microbial influences on colorectal cancer. Inflamm Bowel Dis. 2011;17(1):396-409. doi: 10.1002/ibd.21354

65. Prosekov A, Dyshlyuk L, Milentyeva I, et al. Antioxidant, antimicrobial and antitumor activity of bacteria of the genus Bifidobacterium, selected from the gastrointestinal tract of human. Integrative Molecular Medicine. 2015;2(5):295-303. doi: 10.15761/ IMM.1000157

66. Galdeano CM, Perdigon G. The probiotic bacterium Lactobacillus casei induces activation of the gut mucosal immune system through innate immunity. Clin Vaccine Immunol. 2006;13(2):219-226. doi: 10.1128/ CVI.13.2.219-226.2006

67. Hatakka K, Holma R, El-Nezami H, et al. The influence of Lactobacillus rhamnosus LC705 together with Propionibacterium freudenreichii ssp. shermanii JS on potentially carcinogenic bacterial activity in human colon. Int J Food Microbiol. 2008;128(2):406-410. doi: 10.1016/j.ijfoodmicro.2008.09.010

68. Ohara T, Yoshino K, Kitajima M. Possibility of preventing colorectal carcinogenesis with probiotics. HepatoGastroenterology. 2010;57(104):1411-1415.

69. Madsen KL. Enhancement of epithelial barrier function by probiotics. Journal of Epithelial Biology and Pharmacology. 2012;5(1):55-59. doi: 10.2174/1875044301205010055

70. Gamallat Y, Meyiah A, Kuugbee ED, et al. Lactobacillus rhamnosus induced epithelial cell apoptosis, ameliorates inflammation and prevents colon cancer development in an animal model. Biomed Pharmacother. 2016;83:536-541. doi: 10.1016/j. biopha.2016.07.001

71. Roy S, Trinchieri G. Microbiota: a key orchestrator of cancer therapy. Nat Rev Cancer. 2017;17(5):271-285. doi: 10.1038/nrc.2017.13

72. Grivennikov SI, Wang K, Mucida D, et al. Adenomalinked barrier defects and microbial products drive IL-23/IL-17-mediated tumour growth. Nature. 2012;491(7423):254-258. doi: 10.1038/nature11465

73. Gao C, Ganesh BP, Shi Z, et al. Gut microbe-mediated suppression of inflammation-associated colon carcinogenesis by luminal histamine production. Am J Pathol. 2017;187(10):2323-2336. doi: 10.1016/j. ajpath.2017.06.011

74. Kuugbee ED, Shang X, Gamallat $Y$, et al. Structural change in microbiota by a probiotic cocktail enhances the gut barrier and reduces cancer via TLR2 signaling in a rat model of colon cancer. Dig Dis Sci. 2016;61(10):2908-2920. doi: 10.1007/s10620-0164238-7

75. Yeung $C-Y$, Chan $\mathrm{W}-\mathrm{T}$, Jiang $\mathrm{C}-\mathrm{B}$, et al. Amelioration of chemotherapy-induced intestinal mucositis by orally 
administered probiotics in a mouse model. PloS One. 2015;10(9):e0138746. doi: 10.1371/journal. pone. 0138746

76. Zitvogel L, Ma Y, Raoult D, Kroemer G, Gajewski TF. The microbiome in cancer immunotherapy: Diagnostic tools and therapeutic strategies. Science. 2018;359(6382):1366-1370. doi: 10.1126/science. aar6918

77. Drago L. Chloramphenicol Resurrected: A Journey from Antibiotic Resistance in Eye Infections to Biofilm and Ocular Microbiota. Microorganisms. 2019;7(9):278. doi: $10.3390 /$ microorganisms7090278

78. Viswanath B. Recent Developments in Applied Microbiology and Biochemistry. Academic Press. 2018.

79. Nordestgaard BG, Varbo A. Triglycerides and cardiovascular disease. The Lancet. 2014;384(9943):626-635. doi: 10.1016/S01406736(14)61177-6

80. Safavi M, Farajian S, Kelishadi R, Mirlohi M, Hashemipour $M$. The effects of synbiotic supplementation on some cardio-metabolic risk factors in overweight and obese children: a randomized triple-masked controlled trial. Int J Food Sci Nutr. 2013;64(6):687-693. doi: 10.3109/09637486.2013.775224

81. Hashempour-Baltork F, Torbati M, Azadmard-Damirchi S, Savage GP. Quality properties of sesame and olive oils incorporated with flaxseed oil. Adv Pharm Bull. 2017;7(1):97-101. doi: 10.15171/apb.2017.012

82. Kumar M, Nagpal R, Kumar R, et al. Cholesterol-lowering probiotics as potential biotherapeutics for metabolic diseases. Exp Diabetes Res. 2012;2012:902917. doi: 10.1155/2012/902917

83. Parvez S, Malik KA, Ah Kang S, Kim HY. Probiotics and their fermented food products are beneficial for health. J App/ Microbiol. 2006;100(6):1171-1185. doi: 10.1111/j.1365-2672.2006.02963.x

84. Brown CT, Davis-Richardson AG, Giongo A, et al. Gut microbiome metagenomics analysis suggests a functional model for the development of autoimmunity for type 1 diabetes. PloS One. 2011;6(10):e25792. doi: 10.1371/journal.pone.0025792

85. Bhathena J, Martoni C, Kulamarva A, Urbanska AM, Malhotra M, Prakash S. Orally delivered microencapsulated live probiotic formulation lowers serum lipids in hypercholesterolemic hamsters. J Med Food. 2009;12(2):310-319. doi: 10.1089/ jmf.2008.0166

86. Wang Y, Xu N, Xi A, Ahmed Z, Zhang B, Bai X. Effects of Lactobacillus plantarum MA2 isolated from Tibet kefir on lipid metabolism and intestinal microflora of rats fed on high-cholesterol diet. App/ Microbiol Biotechnol. 2009;84(2):341-347. doi: 10.1007/s00253-009-2012-x

87. Nilsson A, Ostman E, Preston T, Bjorck I. Effects of GI vs content of cereal fibre of the evening meal on glucose tolerance at a subsequent standardized breakfast. Eur J Clin Nutr. 2008;62(6):712-720. doi: 10.1038/ sj.ejcn.1602784

88. Nilsson AC, Ostman EM, Holst JJ, Bjorck IM. Including indigestible carbohydrates in the evening meal of healthy subjects improves glucose tolerance, lowers inflammatory markers, and increases satiety after a subsequent standardized breakfast. J Nutr.
2008;138(4):732-739. doi: 10.1093/jn/138.4.732

89. De Vrese $M$, Schrezenmeir J. Probiotics and non-intestinal infectious conditions. Br J Nutr. 2002;88(S1):s59-s66. doi: 10.1079/BJN2002630

90. Behzadi P, Behzadi E, Pawlak-Adamska EA. Urinary tract infections (UTIs) or genital tract infections (GTIs)? It's the diagnostics that count. GMS Hygiene and Infection Control. 2019;14. doi: 10.3205/dgkh000320

91. Medina M, Castillo-Pino E. An introduction to the epidemiology and burden of urinary tract infections. Therapeutic Advances in Urology. 2019;11:3-7. doi: 10.1177/1756287219832172

92. Cribby S, Taylor M, Reid G. Vaginal microbiota and the use of probiotics. Interdiscip Perspect Infect Dis. 2008;2008:256490. doi: 10.1155/2008/256490

93. Reid G, Bruce AW. Selection of Lactobacillus strains for urogenital probiotic applications. The Journal of Infectious Diseases. 2001;183(Suppl 1):S77-S80. doi: 10.1086/318841

94. Ghadimi D, de Vrese M, Heller KJ, Schrezenmeir J. Lactic acid bacteria enhance autophagic ability of mononuclear phagocytes by increasing Th1 autophagypromoting cytokine (IFN- $-\gamma$ ) and nitric oxide (NO) levels and reducing Th2 autophagy-restraining cytokines (IL-4 and IL-13) in response to Mycobacterium tuberculosis antigen. Int Immunopharmacol. 2010;10(6):694-706. doi: 10.1016/j.intimp.2010.03.014

95. Freitas AC, Hill JE. Quantification, isolation and characterization of Bifidobacterium from the vaginal microbiomes of reproductive aged women. Anaerobe. 2017;47:145-156. doi: 10.1016/j. anaerobe.2017.05.012

96. Borchert D, Sheridan L, Papatsoris A, et al. Prevention and treatment of urinary tract infection with probiotics: review and research perspective. Indian Journal of Urology. 2008;24(2):139-144. doi: 10.4103/09701591.40604

97. Talebi Tm, Niksolat M, Minaeian S, Khodabandelou N, Zandieh Z. The effect of probiotics in the prevention of urinary tract infections in elderly patients hospitalized in intensive care units. Razi Journal of Medical Sciences. 2017;24(156):32-41.

98. Hosseini M, Yousefifard M, Ataei N, Oraii A, Razaz JM, Izadi A. The efficacy of probiotics in prevention of urinary tract infection in children: A systematic review and meta-analysis. Journal of Pediatric Urology. 2017;13(6):581-591. doi: 10.1016/j.jpurol.2017.08.018

99. Brown SJ, Irvine AD. Atopic eczema and the filaggrin story. In Seminars in cutaneous medicine and surgery. 2008: 128-137.

100. Wright RJ, Enlow MB. Maternal stress and perinatal programming in the expression of atopy. Expert Rev Clin Immunol. 2008;4(5):535-538. doi: 10.1586/1744666X.4.5.535

101. Hoare C, Po ALW, Williams H. Systematic review of treatments for atopic eczema. Health technology assessment. 2001;4(37). doi: 10.3310/hta4370

102. Bjorksten B, Sepp E, Julge K, Voor T, Mikelsaar M. Allergy development and the intestinal microflora during the first year of life. J Allergy Clin Immunol. 2001;108(4):516-520. doi: 10.1067/mai.2001.118130

103. Watanabe S, Narisawa Y, Arase S, et al. Differences 
in fecal microflora between patients with atopic dermatitis and healthy control subjects. J Allergy Clin Immunol. 2003;111(3):587-591. doi: 10.1067/ mai.2003.105

104. Boyle RJ, Bath-Hextall FJ, Leonardi-Bee J, Murrell DF, Tang ML. Probiotics for treating eczema. Cochrane Database Syst Rev. 2008;(4). doi: 10.1002/14651858. CD006135.pub2

105. Blanchet-Rethore S, Bourdes V, Mercenier A, Haddar CH, Verhoeven PO, Andres P. Effect of a lotion containing the heat-treated probiotic strain Lactobacillus johnsonii NCC 533 on Staphylococcus aureus colonization in atopic dermatitis. Clin Cosmet Investig Dermatol. 2017;10:249-257. doi: 10.2147/ CCID.S135529

106. Dimarzio L, Cinque B, Cupelli F, De Simone C, Cifone $M$, Giuliani $M$. Increase of skin-ceramide levels in aged subjects following a short-term topical application of bacterial sphingomyelinase from Streptococcus thermophilus. Int J Immunopathol Pharmacol. 2008;21(1):137-143. doi: $10.1177 / 039463200802100115$

107. Gueniche A, Hennino A, Goujon C, et al. Improvement of atopic dermatitis skin symptoms by Vitreoscilla filiformis bacterial extract. Eur J Dermatol. 2006;16(4):380-384.

108. Sicherer SH, Sampson HA. Food allergy. J Allergy Clin Immunol. 2010;125(2):S116-S125. doi: 10.1016/j. jaci.2009.08.028

109. Malin SW, Lutfi R, Friedman ML, Teagarden AM. Food protein-induced enterocolitis syndrome causing hypovolemic shock and methemoglobinemia. Case Reports in Critical Care. 2018;2018:1903787 doi: $10.1155 / 2018 / 1903787$

110. Malin $\mathrm{M}$, Verronen $\mathrm{P}$, Korhonen $\mathrm{H}$, et al. Dietary therapy with Lactobacillus GG, bovine colostrum or bovine immune colostrum in patients with juvenile chronic arthritis: evaluation of effect on gut defence mechanisms. Inflammopharmacology. 1997;5(3):219236. doi: 10.1007/s10787-997-0001-1

111. Hardy H, Harris J, Lyon E, Beal J, Foey AD. Probiotics, prebiotics and immunomodulation of gut mucosal defences: homeostasis and immunopathology. Nutrients. 2013;5(6):1869-1912. doi: 10.3390/ nu5061869

112. Liu M-Y, Yang Z-Y, Dai W-K, et al. Protective effect of Bifidobacterium infantis CGMCC313-2 on ovalbumininduced airway asthma and $\beta$-lactoglobulin-induced intestinal food allergy mouse models. World J Gastroenterol. 2017;23(12):2149-2158. doi: 10.3748/ wjg.v23.i12.2149

113. Pessi T, Isolauri E, Sutas $Y$, Kankaanranta H, Moilanen $E$, Hurme M. Suppression of T-cell activation by Lactobacillus rhamnosus GG-degraded bovine casein. Int Immunopharmacol. 2001;1(2):211-218. doi: 10.1016/S1567-5769(00)00018-7

114. Homayouni-rad A, Fathi-zavoshti H, Douroud $\mathrm{N}$, Shahbazi N, Abbasi A. Evaluating the Role of Postbiotics as a New Generation of Probiotics in Health and Diseases. Journal of Ardabil University of Medical Sciences. 2020;19(4):381-399. doi: 10.29252/ jarums.19.4.381
115. Food allergies: What you need to know. (medicalnewstoday). 2017.

116. Oak SJ, Jha R. The effects of probiotics in lactose intolerance: a systematic review. Crit Rev Food Sci Nutr. 2019;59(11):1675-1683. doi: 10.1080/10408398.2018.1425977

117. Rampengan NH, Manoppo J, Warouw SM. Comparison of efficacies between live and killed probiotics in children with lactose malabsorption. Southeast Asian $J$ Trop Med Public Health. 2010;41(2):474-481.

118. Zhong $Y$, Priebe MG, Vonk RJ, et al. The role of colonic microbiota in lactose intolerance. Dig Dis Sci. 2004;49(1):78-83. doi: 10.1023/B:DDAS.0000011606.96795.40

119. Saltzman JR, Russell RM, Golner B, Barakat S, Dallal $\mathrm{GE}$, Goldin BR. A randomized trial of Lactobacillus acidophilus BG2FO4 to treat lactose intolerance. Am J Clin Nutr. 1999;69(1):140-146. doi: 10.1093/ ajcn/69.1.140

120. Ojetti V, Gigante G, Ainora ME, et al. S1213 the effect of oral supplementation with lactobacillus reuteri or tilactase in lactose-intolerant patients: a placebo controlled study. Gastroenterology. 2009;136(5):A214. doi: 10.1016/S0016-5085(09)60962-8

121. Burton JP, Drummond BK, Chilcott CN, et al. Influence of the probiotic Streptococcus salivarius strain M18 on indices of dental health in children: a randomized double-blind, placebo-controlled trial. J Med Microbiol. 2013;62(6):875-884. doi: 10.1099/jmm.0.056663-0

122. Reddy JJ, Sampathkumar N, Aradhya S. Probiotics in dentistry: review of the current status. Archives of Oral Research. 2010; 29;6(3). doi: 10.7213/aor.v6i3.23163

123. AM P, Costacurta $M$, Fortunato $L$, et al. The probiotics in dentistry: a narrative review. Eur Rev Med Pharmacol Sci. 2017;21(6):1405-1412.

124. Caglar E, Kargul B, Tanboga I. Bacteriotherapy and probiotics' role on oral health. Oral Diseases. 2005;11(3):131-137. doi: 10.1111/j.16010825.2005.01109.x

125. Haukioja A, Yli-Knuuttila $\mathrm{H}$, Loimaranta $\mathrm{V}$, et al. Oral adhesion and survival of probiotic and other lactobacilli and bifidobacteria in vitro. Oral Microbiol Immunol. 2006;21(5):326-332. doi: 10.1111/j.1399302X.2006.00299.x

126. Kekkonen RA, Lummela $\mathrm{N}$, Karjalainen $\mathrm{H}$, et al. Probiotic intervention has strain-specific anti-inflammatory effects in healthy adults. World J Gastroenterol. 2008;14(13):2029-2036. doi: 10.3748/wjg.14.2029

127. Marsh PD. Are dental diseases examples of ecological catastrophes? Microbiology. 2003;149(2):279-294. doi: 10.1099/mic.0.26082-0

128. Paineau D, Carcano D, Leyer G, et al. Effects of seven potential probiotic strains on specific immune responses in healthy adults: a double-blind, randomized, controlled trial. FEMS Immunology \& Medical Microbiology. 2008;53(1):107-113. doi: 10.1111/j.1574-695X.2008.00413.x

129. Comelli EM, Guggenheim B, Stingele F, Neeser JR. Selection of dairy bacterial strains as probiotics for oral health. Eur J Oral Sci. 2002;110(3):218-224. doi: 10.1034/j.1600-0447.2002.21216.x

130. Kang M-S, Chung J, Kim S-M, Yang K-H, Oh J-S. Effect 
of Weissella cibaria isolates on the formation of Streptococcus mutans biofilm. Caries Research. 2006;40(5):418-425. doi: 10.1159/000094288

131. Shimazaki Y, Shirota T, Uchida K, et al. Intake of dairy products and periodontal disease: the Hisayama Study. J Periodontol. 2008;79(1):131-137. doi: 10.1902/ jop.2008.070202

132. Schwendicke F, Korte F, Dörfer CE, Kneist S, El-Sayed $\mathrm{KF}$, Paris S. Inhibition of Streptococcus mutans growth and biofilm formation by probiotics in vitro. Caries Research. 2017;51(2):87-95. doi: 10.1159/000452960

133. Schwendicke F, Dorfer C, Kneist S, MeyerLueckel H, Paris S. Cariogenic effects of probiotic Lactobacillus rhamnosus GG in a dental biofilm model. Caries Research. 2014;48(3):186-192. doi: 10.1159/000355907

134. Oliveira LF, Salvador SL, Silva PH, et al. Benefits of Bifidobacterium animalis subsp. lactis probiotic in experimental periodontitis. J periodontol. 2017;88(2):197-208. doi: 10.1902/jop.2016.160217

135. Prentice AM. The emerging epidemic of obesity in developing countries. Int J Epidemiol. 2006;35(1):9399. doi: $10.1093 / \mathrm{ije} /$ dyi272

136. Eckburg PB, Bik EM, Bernstein CN, et al. Diversity of the human intestinal microbial flora. Science. 2005;308(5728):1635-1638. doi:10.1126/ science.1110591

137. Ley RE, Backhed F, Turnbaugh P, Lozupone CA, Knight RD, Gordon JI. Obesity alters gut microbial ecology. Proc Natl Acad Sci U S A. 2005;102(31):11070-11075. doi: 10.1073/pnas.0504978102

138. Ley RE, Turnbaugh PJ, Klein S, Gordon JI. Microbial ecology: human gut microbes associated with obesity. Nature. 2006;444(7122):1022-1023. doi:10.1038/4441022a
139. Turnbaugh PJ, Hamady M, Yatsunenko T, et al. A core gut microbiome in obese and lean twins. Nature. 2009;457(7228):480-484. doi:10.1038/nature07540

140. Turnbaugh PJ, Ley RE, Mahowald MA, Magrini V, Mardis ER, Gordon JI. An obesity-associated gut microbiome with increased capacity for energy harvest. Nature. 2006;444(7122):1027-1031. doi: 10.1038/nature05414

141. Ogawa A, Kobayashi T, Sakai F, Kadooka Y, Kawasaki Y. Lactobacillus gasseri SBT2055 suppresses fatty acid release through enlargement of fat emulsion size in vitro and promotes fecal fat excretion in healthy Japanese subjects. Lipids in health and disease. 2015;14:20. doi: 10.1186/s12944-015-0019-0

142. Yadav H, Lee JH, Lloyd J, Walter P, Rane SG. Beneficial metabolic effects of a probiotic via butyrateinduced GLP-1 hormone secretion. I Biol Chem. 2013;288(35):25088-25097. doi: 10.1074/jbc. M113.452516

143. Aronsson L, Huang $Y$, Parini $P$, et al. Decreased fat storage by Lactobacillus paracasei is associated with increased levels of angiopoietin-like 4 protein (ANGPTL4). PLoS One. 2010;5(9):e13087. doi: 10.1371/ journal.pone.0013087

144. Pereira SS, Alvarez-Leite JI. Low-Grade Inflammation, Obesity, and Diabetes. Curr Obes Rep. 2014;3(4):422431. doi: 10.1007/s13679-014-0124-9

145. Higashikawa F, Noda M, Awaya T, et al. Antiobesity effect of Pediococcus pentosaceus LP28 on overweight subjects: a randomized, double-blind, placebocontrolled clinical trial. Eur J Clin Nutr. 2016;70(5):582587. doi: 10.1038/ejcn.2016.17

146. Miyoshi M, Ogawa A, Higurashi S, Kadooka Y. Antiobesity effect of Lactobacillus gasseri SBT2055 accompanied by inhibition of pro-inflammatory gene expression in the visceral adipose tissue in dietinduced obese mice. Eur J Clin Nutr. 2014;53(2):599606. doi: 10.1007/s00394-013-0568-9 